\title{
Agriculture Management and Soil Fauna Monitoring: The Case of Emilia-Romagna Region (Italy)
}

\author{
Cristina Menta ${ }^{1 *}$, Beatrice Bonati ${ }^{1}$, Francesca Staffilani ${ }^{2}$ and Federica Delia Conti \\ ${ }^{1}$ Department of Chemistry,Life Sciences and Environmental Sustainability, University of Parma, Italy \\ ${ }^{2}$ Geological, Seismic and Soil Survey - Regione Emilia-Romagna, Italy
}

Submission: March 01, 2017; Published: March 14, 2017

*Corresponding author: Cristina Menta, Department of Chemistry, Life Sciences and Environmental Sustainability, University of Parma, Parco Area delle Scienze 11/A, 43124 Parma, Italy, Tel: +390521903407; Email: cristina.menta@uniprit

\begin{abstract}
It is known that intensive human land use has an impact on soil state and functioning. Soil fauna diversity is a validated tool to assess soil quality. Here we analyzed soil arthropods community in several agricultural managements (arable land, grassland, vineyard and orchard) located in the Emilia-Romagna region (Italy), whose land was especially exploited for intensive agriculture, in order to state soil health and soil quality, in relation to crop types and management. The computation of the biological soil quality index QBS-ar revealed lower values in arable lands, easily due to management practices applied, in particular ploughing. On the other hand, the QBS-ar values associated to orchards and vineyards were higher: the grassy cover on soil and the reduced farming practices support soil microarthropod communities. Meadows were generally characterized by high index values, related to their age. The application of QBS-ar index as a tool to identify soil quality and, thus, soil functionality, was then confirmed. Starting with this type of approach, further analyses could be crucial to highlight differences between managements applied in each use we considered, and to suggest some principles for a soil fauna diversity sustainable agriculture.
\end{abstract}

Keywords: Soil biological quality; Microarthropod; Quality index; Soil biodiversity; Soil fauna; Soil use

\section{Introduction}

During the last century, soils have been over-exploited by humans through agriculture and industrial development, and the need to assess different aspects of soil degradation has become a priority in the soil protection management. Besides the obvious implications for agro-sylvo-pastoral production, soils take part in the provision of regulative services such as carbon sequestration [1], flood control, detoxification, protection of plants against pests, and others [2]. The high and still in part unknown biodiversity that characterizes soils is a pivotal element that sustains soil functions so that they provide a paradigmatic example of the relation between biodiversity and ecosystem services, an issue that is of prime importance in the international research agenda $[3,4]$. From this descends that studying soil biodiversity is essential for understanding soil ecological functions and their capability to provide services [5]. Soil capability to perform ecological functions is often referred to as soil quality.
Intensive agriculture, characterized by a massive use of inputs (fertilizers, herbicides, pesticides, etc.) and practices (tillage, different rotations per year, irrigation, etc.) to maximize harvest, has negative local, regional, and global consequences on above and below-ground biodiversity [6], on soil organic matter and thus on soil carbon content [7]. Accordingly, it reduces soil quality [8]. In particular, carbon loss has been showed in agroecosystems, but a wise management (e.g., no-till, cover crops, green, or animal manure) could reduce the rate and the amount of this loss $[7,9]$.

There is no a universally applicable formula to measure soil quality [10] and for soils a fully efficient bioindicator toolbox does not exist yet [11]. Most of the difficulties concerning the application of the existing indices are related to the poor standardization of the methods and face problems associated with the spatial scale at which they can be applied [10]. The QBSar is one of the indices that have been conceived and developed 
in recent years [12]. It is a metric based on the concept that the number of microarthropod groups morphologically well adapted to soil is higher in high quality soils than in low quality soils. QBS-ar joins the biodiversity of soil microarthropods community with the degree of soil animals' vulnerability and provides information on the soil biological quality, which is an indicator of land degradation. The potential of QBS-ar is recognized and this is witnessed by the increased number of applications in Italy and in European and non-European countries [13,24].

This paper reports the results obtained applying a soil quality monitoring plan carried out by the Emilia-Romagna region (Northern Italy), and still in progress. This monitoring plan takes into account several agriculture managements with the aim to quantify different impacts on soil biological quality and diversity. In this paper we report soil biological quality, expressed as QBSar value, detected in 43 agriculture soils that differed in terms of crop types (cereals, permanent grasslands, alfalfa, meadows, orchards, and vineyard) or managements (conventional, no-till, organic).

\section{Methods}

Soil sampling for soil microarthropod extraction occurred in Spring and Autumn 2015 in 43 sites (3 replicates per site) in Emilia-Romagna region (North-East of Italy). The 43 sites were distributed in 4 land uses: Arable land (15 sites), Vineyard (9), Orchard (4) and meadow (15 sites). In this latter, three different sub-categories were considered depending from the age of the meadow: Rotation meadows are involved in the rotation of cultures for less than 5 years; Permanent meadows are alfalfa crop or polyphite grass older than 5 years but under 30 years; Stable meadows have more than 30 years.

Table 1: Soil uses, number of sites, crop types and managements of the soils inserted in the Emilia-Romagna project.

\begin{tabular}{|c|c|c|c|}
\hline Soil Use & $\begin{array}{c}\text { Number } \\
\text { of sites }\end{array}$ & Croptypes & Practices \\
\hline $\begin{array}{c}\text { Arable } \\
\text { Land }\end{array}$ & 15 & $\begin{array}{c}\text { Wheat, Sorghum, } \\
\text { Barley, Maize }\end{array}$ & $\begin{array}{c}\text { Conventional Tillage, } \\
\text { No-till, Subirrigation }\end{array}$ \\
\hline \multirow{2}{*}{ Grassland } & 5 & Alfalfa or polyphita & $\begin{array}{c}\text { Rotation meadow } \\
(<5 \text { years })\end{array}$ \\
\cline { 2 - 4 } & 2 & Polyphita & $\begin{array}{c}\text { Permanent meadow } \\
(5-30 \text { years })\end{array}$ \\
\hline Orchard & 9 & Pear, Peachtrees & $\begin{array}{c}\text { Stable meadow } \\
(>30 \text { years })\end{array}$ \\
\hline Vineyard & 4 & Grapes & $\begin{array}{c}\text { Integrated, Organic } \\
\text { fraditional } \\
\text { farming }\end{array}$ \\
\hline
\end{tabular}

Table 1 reports the number of sites studied for each soil use. Arthropod extraction was performed by Berlese-Tüllgren funnel (extraction time 10 days). The specimens were placed in a preservative solution ( $75 \%$ ethyl alcohol and $25 \%$ glycerol by volume) and identified to class level for Myriapoda, order level for Hexapoda, Chelicerata and Insecta, as provided by QBS-ar method [12]. For the QBS-ar index computation, an ecologicalmorphological index (EMI), ranged between 1 and 20, is assigned for each taxon. QBS-arindex resulted as the sum of the highest EMI values of the three replicationsrelative to each taxon [12].

A two-way ANOVA was applied to highlight variability in the QBS-ar index, seasons and soil managements. Tukey's pair wise for the comparison of significant values ( $p$-value $<0.05$ ) was carried out for post-hoc analysis. The Student $t$ test for paired sample comparisons was applied to evaluate seasonality effect inside each soil use category. All the statistical analyses were performed using R 3.0.2statistical software [25].

\section{Results and Discussion}

The results highlighted some differences between the six categories considered (Figure 1), due to land use $(\mathrm{p}<0.001)$ and not to the sampling season $(\mathrm{p}=0.71)$. Arable lands were significantly different from rotation and permanent meadows $(\mathrm{p}<0.001$ both), vineyard $(\mathrm{p}<0.001)$ and orchard $(\mathrm{p}<0.001)$, except stable meadows $(p>0.05)$. Among the meadows, permanent ones were different from the other two $(\mathrm{p}<0.05$ with rotation and $p<0.001$ in relation to stable meadows). Vineyards and orchards differed too each other $(\mathrm{p}<0.05)$.

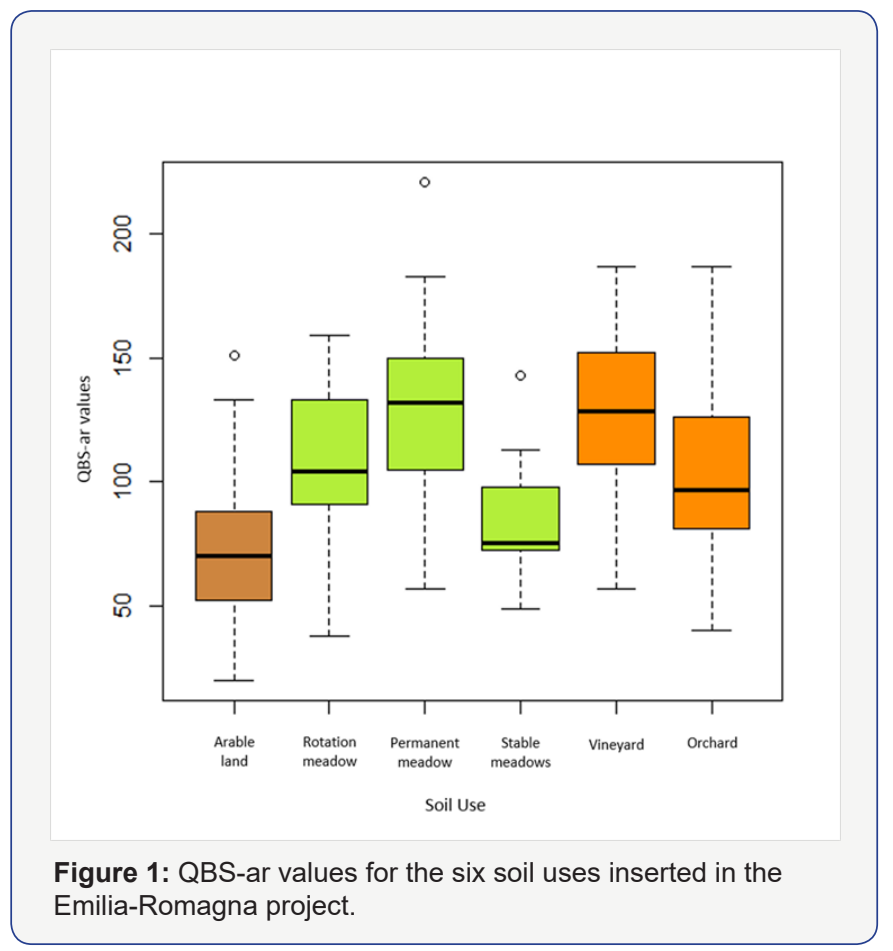

Arable land was characterized by the lowest QBS-ar value, the annual crops by values ranged between 20 and 151 (average value 71.1, SD 26.7). These results did not differ from those found in previous studies $[12,18,24,26]$, outlining that the practices used in arable lands, in particular ploughing, affect soil habitat and soil community composition and, thus, the QBSar index. In these sites the number of well-adapted groups of 
microarthropods, then much more vulnerable, results low. The high variability in this category should be further investigated as it allows to find out the effects of several practices, some of these more sustainable like no-tillage or minimum tillage, in order to minimize the detrimental impact on soil living community. Meadows (rotation, permanent and stable meadows) reached higher values of the index (Figure 1), in particular for the absence of tillage and a major protection of the soil surface. More in detail, the first two categories showed higher QBS-ar values than the third one: the rotation meadow ranged between 38 and 159 (average value 107.7, SD30.3), the permanent meadow between 57 and 183 (average value 131.7, SD 34.7), while stable meadow ranged between 49 and 143 (average value 83.9, SD25.9). These differences could be due to the effects of the grass roots on the soil surface layer, but further analyses will be useful to clarify this aspect. The more diversified plant composition could affect soil compaction and soil properties positively in the rotation and permanent meadows, and, consequently, soil biodiversity. Vineyards and orchards showed high QBS-ar values, with an average of 128.3 (SD 34.1) and 103.1 (SD 34.3) respectively. The Vineyard value is comparable to the Permanent meadow value. The soil between the rows was grassy covered and little disturbed in Vineyard and Orchard, explaining the high QBS-ar values and the richness in soil micro arthropod community in these two categories. Similar results were reported in $[13,19]$.

In the end, we can affirm that the land use had the greatest impact on soil micro arthropod community, and consequently on QBS-ar values. On the one hand, the impact of agricultural practices in the arable land was shown through a simplification in the micro arthropod communities, with a reduced number of specimens well-adapted to soil. In contrast, a reduced management and a grassy cover affected positively soil micro arthropod communities.

Considering the QBS-ar index, it is confirmed to be a good and cheaper application tool for describing soil quality and, extensively, soil biodiversity. Furthermore, it can represent a worthwhile starting point to underline some good practices that should be applied on soil (such as sustainable practices, no-tillage or minimum tillage) in order to maintain and enhance soil living community and, consequently, soil functionality and biological quality.

\section{Acknowledgements}

This research was partially funded by the Emilia-Romagna project.

\section{References}

1. Gardi C, Visioli G, Conti FD, Scotti M, Menta C, et al. (2016) High nature value farmland: assessment of soil organic carbon in Europe. Front Environ Sci 4(47): 1-10.

2. Jeffery S, Harris JA, Rickson RJ, Ritz K (2010) Effects of soil-surface microbial community phenotype upon physical and hydrological properties of an arable soil: A microcosm study. Eur J Soil Sci 61(4): 493-503.
3. Mace GM, Norris K, Fitter AH (2012) Biodiversity and ecosystem services: A multilayered relationship. Trends Ecol Evol 27(1): 19-25.

4. Maes J, Teller A, Erhard M, Murphy P, Paracchini ML, et al. (2014) Mapping and Assessment of Ecosystems and their Services. Indicators for ecosystem assessments under Action 5 of the EU Biodiversity Strategy to 2020. Publications office of the European Union, Luxembourg, Europe.

5. Lavelle P, Decaëns T, Aubert M, Barot S, Blouin M, et al. (2006) Soil invertebrates and ecosystem services. Eur J Soil Biol 42: S3-S15.

6. Tsiafouli MA, Thébault E, Sgardelis SP, deRuiter PC, Putten WHV, et al. (2015) Intensive agriculture reduces soil biodiversity across Europe. Glob Change Biol 21: 973-985.

7. Matson PA, Parton WJ, Power AG, Swift MJ (1997) Agricultural intensification and ecosystem properties. Science 277(5325): 504-509.

8. Karlen DL, Mausbach MJ, Doran JW, Cline RG, Harris RF, et al. (1997) Soil quality: a concept, definition, and framework for evaluation (a Guest Editorial). Soil Sci Society Am J 61: 4-10.

9. Naidoo R, Balmford A, Costanza R, Fisher B, Green RE, et al. (2008) Global mapping of ecosystem services and conservation priorities. Proc Natl Acad Sc USA 105(28): 9495-9500.

10. Bastida F, Zsolnay A, Hernández T, García C (2008) Past, present and future of soil quality indices: A biological perspective. Geoderma 147(3-4): 159-171.

11. Havlicek E (2012) Soil biodiversity and bioindication: From complex thinking to simple acting. Eur J Soil Biol 49: 80-84.

12. Parisi V, Menta C, Gardi C, Jacomini C, Mozzanica E (2005) Microarthropod communities as a tool to assess soil quality and biodiversity: a new approach in Italy. Agr Ecosyst Environ 105: 323333.

13. Blasi S, Menta C, Balducci L, Conti FD, Petrini E, et al. (2013) Soil micro arthropod communities from Mediterranean forest ecosystems in Central Italy under different disturbances. Environ Monit Assess 185(2): 1637-1655.

14. Galli L, Capurro M, Menta C, Rellini I (2014) Is the QBS-ar index a good tool to detect the soil quality in Mediterranean areas? A cork tree Quercussuber L. (Fagaceae) wood as a case of study. Ital J Zool 81: 126135.

15. Hartley W, Uffindell L, Plumb A, Rawlinson HA, Putwain P, et al. (2008) Assessing biological indicators for remediated anthropogenic urban soils. Sc Total Environ 405(1-3): 358-369.

16. Madej G, Barkzyk G, Gdawiec M (2011) Evaluation of soil biological quality index (QBS-ar): its sensitivity and usefulness in the postmining chronosequence-Preliminary research. Pol J Environ Stud 20(5): 1367-1372.

17. Menta C, Leoni A, Bardini M, Gardi, C, Gatti F (2008) Nematode and microarthropod communities: comparative use of soil quality bioindicators in covered dump and natural soils. Environ Bioindic 3(1): 35-46.

18. Menta C, Leoni A, Tarasconi K, Affanni P (2010) Does compost use affect micro arthropod soil communities? Fresen Environ Bull 19: 2303-2311.

19. Menta C, Leoni A, Gardi C, Conti FD (2011) Are grasslands important habitats for soil microarthropod conservation? Biodivers Conserv 20: 1073-1087.

20. Menta C, García-Montero LG, Pinto S, Conti FD, Baroni G, et al. (2014a) Does the natural "microcosm" created by Tuber aestivum affect soil microarthropods? A new hypothesis based on Collembola in truffle culture. Applied Soil Ecology 84: 31-37. 
21. Menta C, Conti FD, Pinto S, Leoni A, Lozano-Fondón C (2014b) Monitoring soil restoration in an open-pit mine in northern Italy. Applied Soil Ecology 83: 22-29.

22. Menta C, Tagliapietra A, Caoduro G, Zanetti A, Pinto S (2015) Ibs-Bf and Qbs-Arcomparison: two quantitative indices based on soil fauna community. EC Agriculture 2(5): 427-439.

23. Rüdisser J, Tasser E, Peham T, Meyer E, Tappeiner U (2015) The dark side of biodiversity: Spatial application of the biological soil quality indicator (BSQ). Ecol Indic 53: 240-246.

This work is licensed under Creative Commons Attribution 4.0 License

DOI: $10.19080 /$ ARTOAJ.2017.04.555649
24. Tabaglio V, Gavazzi C, Menta C (2009) Physico-chemical indicators and microarthropod communities as influenced by no-till, conventional tillage and nitrogen fertilization after four years of continuous maize. Soil Till Res 105(1): 135-242.

25. R Core Team (2015) R: A language and environment for statistical computing. R Foundation for Statistical Computing, Vienna, Austria.

26. Tabaglio V, Gavazzi C, Menta C (2008) The influence of no-till, conventional tillage and nitrogen fertilization on physico-chemical and biological indicators after three years of monoculture barley. Ital J Agron 3(4): 233-240.

\section{Your next submission with Juniper Publishers will reach you the below assets}

- Quality Editorial service

- Swift Peer Review

- Reprints availability

- E-prints Service

- Manuscript Podcast for convenient understanding

- Global attainment for your research

- Manuscript accessibility in different formats (Pdf, E-pub, Full Text, Audio)

- Unceasing customer service

Track the below URL for one-step submission https://juniperpublishers.com/online-submission.php 